\title{
A CRITICAL ANALYSIS OF TODAY'S ACCOUNTING AND COST CALCULATION SYSTEM IN WOOD INDUSTRY
}

\author{
Ph.D. Student Dorin Munteanu, "Valahia” University, Târgoviste
}

\begin{abstract}
The present work represents a critical analysis of the accounting and cost calculation system organization in wood industry, having considered the specific conditions of this area, the theoretical and methodological principles, as well as the implementation of advanced accounting and cost calculation methods.
\end{abstract}

To set up the management accounting and the calculation of costs in the wood processing industry we take in account as it is normal some specific factors in the field and the methodological and theoretical principles developed by the Romanian school in agreement with the international theory and practice in the field. The first Romanian author that approaches and debates in specialty papers with accounting profile the problem of the importance, of the structure and of the setting of the production cost ids the teacher Constantin Petrescu from Iasi. In his paper entitle "Management and Accounting Convention" (Iasi, 1901) he defines the cost like the others French authors, under the influence of which was found: "the reversion price". Stating with the year 1913, the problems of the management accounting and the calculation of costs, included in the courses of industrial accounting, begin to be studied in the accounted academic education that is founded in Bucharest ${ }^{1}$. The problems related by the scientific calculation of the costs has been debated at the VII national congress of the Qualified Accountants and Certified Accountants from Romania, that took place in Timisoara in the year 1935 and starting with the year 1955, the planed and effective calculation cost of the industrial production, and ulterior of the other branches of the production had a established character through the base rules and starting with the academic year 1969-1970, the management accounting and the calculation of costs, is consisted in a distinct discipline of the academic economic education.

All those evolutions prove that the Romanian school and so the economic accouters from Romania, in time, were acquainted with the problems related with the management accounting and the calculation of costs at an international level the practice from the enterprises it was not far from the application of some advance methods of accounting and calculation. It can be appreciated that the size of the enterprises of wood process from Romania, the organizatory structure of those, the type of structure, the integrated degree, concentration specialization and automatization had been created the necessary condition in order to assimilate the techniques and the methods evaluated by the management accounting and the calculation of costs.

The object of calculation is consisted by the products and the stages given in the fabrication process, the production costs being registered in monthly open accounts on each step so that at the end of the management period by the accumulation of all the expenses from the last part of the production step to obtain the effective cost of the final product.

In the case of the majority of the enterprises from the field of the wood process the calculation cost is realized on the mills (sections), so on the subdivisions from the productivetechnical frame, organizatory and management of the enterprise so that in those enterprises the step of the calculation is the one with the section. In the case of an section, if this has as a production object only one object and at the end of the period it does not have a continuous flow production or goods in process it is used the method of simple division of calculation costs. For example at the

\footnotetext{
${ }^{1}$ Oprea Calin, Gheorghe Carstea, Management accounting and the Calculation of Costs, Publisher house Genicod, 2002.
} 
sections that make steam, compressed air, oxygen, the production cost is transferred monthly at the consumable sections. Further on we follow the reflection of the intern intermediated goods cost on the calculation steps and than the allocation of the production costs between two or more products obtained from the same step.

The critical analysis of this calculation method on steps, revels the limits and the fact that the method does not permit only the practicing of a postoperative control namely the one respecting the pre-established level of the costs. At the same time the step method, does not make possible the operative knowing of the deviations from the normal conditions in process of the production taken in account with the occasion of the budgetary and standard classification of expenses, on types, causes, production places etc. As a fact the given information does not permit on time to see the uneconomic expenses, of some difficulties that interfere in the activity and does not take in account the optimization aspects and the cost minimization.

The complexity and the size of the enterprise of wood processing influenced the organization and the making process of specific functions of management accounting organized in different structures (departments, directions, services, birous, compartments, after case), in which work the bigger part of personal with proper preparation.

The computer information used to subordinate in general the consecrated rules of accounting namely to respect the accounting principles (prudence, exercises independence, uncompensated etc.) of the accounting evaluation methods of the initial cost, production, the inventory evaluation etc., respecting the rules regarding the needs of elaboration and circulation of the documents in which were registered the accounting information's adapted to the specific units involved, respecting the minimal criteria regarding the computer programs used in the financial accounting field approved by the OMFP nr.425/1998 and so on.

From the point of view to respect the evaluation rules of the production cost of the final goods and the one of the unfinished production, some limits regarding the partial process costing in concordance with the accounting settlements persisted in time, almost in every enterprise of the wood processing industry. Also, we have to point out some other critical aspects such as:

- The un-entry and not following the cost of the sub-activities in some enterprises, even though some arias are not working at their full capacity. In this situation the products costs of the stored products are influenced (increased) with tho se expenses due to the sub-activities;

- Not respecting in some cases the methodological norms of function of the accounts by registering in the expenses accounts of the management accounting some expenses that are not the allocated object suitable with the distribution processes specific to the management accounting;

-the rules incorporated in the costs of certain categories of expenses, as there are the general management expenses, in some cases they not take in account the need of rational distribution, namely they not take in account the connection between the expense made and the raw material inventory;

-applying the accounting method (indirect) in order to determinate the production costs reimbursed on the production in a small measure or only at the end of the financial exercise it is used the inventory method.

All those limits of the management accounting system and of the calculation of costs practiced can be eliminated gradually as the interest of the stockholder and the other factors grow in the information given by the management accounting.

The accent on the productivity (productive rate) of the resources follows to determine some reducing models of the resources loss resources and of using them efficient no matter if there are financial resources, material, human or techniques, systems and consecrated practices at the enterprise level.

- the concept regarding the management accounting on the new created value has in fact the efficient using of the enterprise resources that can be judged and evaluated only in correlation with 
the generated value on the market of the products and services and the capital market in the interest of all the interested factors (stockholder, employees, clients, community in general etc.)

- the concept regarding the business process of the enterprise it is under the conditions in which the management accounting is centered round the process of business and must assure the agreement of the entirety organizational processes (production, research-development, commercial) with product strategies, services etc., in order to give relevant information on the correlation between the resources consumed and the value generated in time.

-the concept regarding the orientation on teams starts from the fact that the entire activities that concern the management accounting are run and carried on through various teams, concern on the operational activities, strategy, management etc., which are established the necessary responsibilities and the competences.

The classic general accounting it is not sufficient and it comes the management accounting that has the role of the leading instrument of some organizatory technique; she is fast and promotes the expenses established that can be considered "normal" and determines the anomalies and allows the enterprise to act in order to eliminate them.

In order to give with efficiency the information regarding the production costs and on the other hand to develop the anticipated management accounting, it is necessary to promote different methods of calculation of the costs, based on the pre-established expenses. In this direction we know the method standard - cost, as well the combination used different advanced countries such as the method direct-costing, the method on cost centers etc. from all those methods the one that responds better to the necessity of the operative leading of the value side of the production and the efficiency of economic growth, the method standard - cost. This assures to the information's regarding the production costs an operative, anticipated and functional character.

In conclusion we consider that the industry of wood process all those desiderates can be made by using the standard- cost method in the alternative of unique standard - cost. In this way it will be realized the change of the management accounting, from the evidence of historical character that registers and relates the facts without an operative and efficient power of information in a modern leading instrument.

\section{BIBLIOGRAPHY}

1. Bojian, Octavian - The enterprise Accounting, Publisher house Economica, 1999.

2. Briciu Sorin, Informational system regarding the management accounting and the calculation of costs in industry, Publisher house Argus, Bucuresti, 2000, p.103.

3. Briciu Sorin, Managerial Accounting - Practical and theoretical aspects, Publisher house Economica, Bucuresti, 2006, p.87.

4. Briciu Sorin Management and Analitical Accounting Publisher house Ulise, Alba Iulia, 2002.

5. Briciu Sorin, Burja Vasile, Management accounting. The Calculation and the Analyse of Costs, Publisher house ulise, Alba Iulia, 2002.

6. Briciu Sorin, Tamas Szora Attila, Dobra Iulian Bogdan, Sas Florentina, The management accounting of the enterprises from trading, Publisher house Risoprint, Cluj-Napoca, 2005.

7. Calin Oprea, Management accounting, Publisher house Tribuna Economica, Bucuresti, 2000.

8. Calin Oprea, Management accounting, Publisher house Tribuna Economica, Bucuresti, 2002.

9. Calin Oprera, Ristea Mihai "The bases of Accounting", Publisher house Didactica si Pedagogica, Bucuresti, 2003.

10. Calin Oprea, Carstea Gheorghe, Management accounting and the Calculation of Costs, Publisher house Atlas, Bucuresti, 2003. 